\title{
XRF ANALYSIS AS A TOOL FOR IDENTIFICATION OF RESEARCH AT THE PRESENT LEVEL GUNSHOT INJURIES
}

\author{
MishalovV.D., Hoholeva T.V., Petrosak A.U., Gurina O.A., \\ Chihman J.V., Grinchishina A.V., Mikhaylenko A.V.
}

\begin{abstract}
Background.
Optical Spectroscopic techniques are widely used in practice, despite the high sensitivity and wide range studied chemical elements, have the drawback such as sample preparation, which is possible only if the destruction of the object of research. Nondestructive method of investigating the elemental composition of layers of metals and other GSR is micro-XRF, but investigated the possibilities of modern equipment is not enough.

Objective. The study was to identify the distribution of chemical elements in damages simulators clothes at experimental shots from firearms through.

Methods. The objects of study were damaged clothing (patches of skin, which made jacket). Was used micro XRF spectrometer «M4 TORNADO» manufactured by Bruker (Germany).

Results. Technical features and software spectrometer «M4 TORNADO» provides new opportunities for laboratory diagnosis of various chemical elements in the tissues of biological and non-biological origin, including gunshot residue (GSR). The advantages of micro-XRF method are similar in topography mapping capabilities that individual elements and their combinations. In analyzing the nature of the distribution of elements on maps derived researcher has the opportunity to interpret the intensity of the character and background layers of the concentrations of elements that creates the preconditions for refusing the study of the control sample (material outside the target area of damage).
\end{abstract}

Conclusion. new opportunities for laboratory diagnostics GSR by using micro- XRF.

Key words: micro-XRF, Gunshot Residue (GSR).

УДК 612.12-001.45:340.624

\section{ПОРІВНЯЛЬНА СУДОВО-МЕДИЧНА ХАРАКТЕРИСТИКА ПОШКОДЖЕНЬ ЕКСПАНСИВНИМИ КУЛЯМИ, ЩО СПОРЯДЖЕНІ В МИСЛИВСЬКІ ПАТРОНИ 8Х57 ММ, ТАКИХ ТОРГОВИХ МАРОК, ЯK «GECO», «RWS» TA «SELLIER \& BELLOT»}

\author{
СБартошик Н. В. \\ Львівський національний медичний університет імені Данила Галицького
}

Резюме: У статті викладені результати експериментальних досліджень вогнепальних ушкоджень, спричинених мисливськими патрони 8х57мм, споряджених експансивними кулями, різних торгових марок, що проводились по об'єктах біологічного та небіологічного походження з різних відстаней, та представлена судово-медична характеристика спільних та відмінних морфологічних знак.

Ключові слова: Вогнепальні ушкодження, експансивні кулі, відстань пострілу, дефект тканини.

ВСТУП: Постійне вдосконалення вогнепальної зброї, поява її нових зразків залишають дослідження вогнепальних ушкоджень актуальною темою для судових медиків вже протягом століть. При цьому, разом з появою нових взірців зброї і боєприпасів до них, розширюються можливості судово-медичної експертизи вогнепальних ушкоджень завдяки розробці нових методів дослідження [2-4]. Сучасний арсенал вогнепальної мисливської зброї налічує десятки видів як вітчизняного, так і закордонного виробництва. Однією з найбільш розповсюджених в Україні $\epsilon$ мисливська нарізна вогнепальна зброя калібру $8 \times 57$ мм, та великою популярністю користуються такі патрони, як "Geco", "RWS", "Sellier \& Bellot”, що споряджені експансивними кулями. Незважаючи на те, що експансивні кулі відомі вже понад 100 років і у 1899р Першою Гаазькою мирною конвенцією вони були заборонені [1], оскільки спричиняють значні руйнування м'яких тканин, судово-медичної оцінки ушкоджень на тілі й одязі, заподіяних при пострілах мисливськими патронами 8х57 мм не проводилося. Особливо, це актуально, коли куля не залишається в тілі людини, а утворює наскрізне ушкодження, це ускладнює виконання повноцінної судово-медичної експертизи та диференційної діагностики таких поранень, створюючи передумови для експертних помилок.

Мета дослідження - дати судово-медичну характеристику вогнепальних ушкоджень тіла та імітаторів одягу при експериментальних пострілах мисливськими патронами 8х57мм, що споряджені експансивними кулями з різних відстаней пострілу, різними торговими марками та навести ряд їх спільних ознак та відмінностей.

Матеріали та методи дослідження: Для виконання експериментальних пострілів використовувався мисливський карабін Mauser 98К, що заряджався патронами 8х57мм, споряджені експансивними кулями трьох торгових марок, таких як “Geco”, “RWS” та “Sellier \& Bellot”. Також об”єкти, по яких проводили постріли, а саме біологічні об'єкти (ділянки грудної клітки, черевної порожнини та стегна трупа) та імітатори одягу (біла бавовняна тканина та камуфльована тканина). 


\section{РЕЗУЛЬТАТИ ДОСЛІДЖЕННЯ ТА ЇХ ОБГОВОРЕННЯ.}

При здійсненні ряду експериментальних ушкоджень мисливськими патронами 8х57 мм, що споряджені експансивними кулями, різних торгових марок було встановлено як спільні ознаки, так і певні відмінності.

У першу чергу, спільною ознакою цих куль $є$ те, що всі вони експансивні, тобто здатні деформуватися при потраплянні в об’єкт. Проте під час проведення експериментальних пострілів було встановлено ряд відмінностей, тобто кожна з вище досліджених експансивних куль володіє своїм індивідуальним видом експансивності. Куля, що споряджена в патрон “Gесо”, при потраплянні в об’єкт має здатність сплющуватися та деформуватися, деформовані об’ єкти мають розміри від $1,8 \times 2$ до $1,5 \times 2,3$ см, а при потраплянні в кісткову тканину фрагментуватися, утворюючи три та більше окремих деформованих фрагменти розмірами від $0,3 \times 0,5$ см до 1х1,8 см. Куля, що споряджена в патрон “RWS”, після контакту з об'єктом розкривається, суттєво збільшуючи свій діаметр. ІЇ̈ розкриття відбувається у вигляді три- або чотирилистника, листки якого добре фіксовані серцевиною та не утворюють окремих фрагментів. Розміри даних об’єктів були від 2х2,3 до 2,2х2,4 см Куля, що споряджена в патрон “Sellier \& Bellot”, після контакту з об’єктом деформується, збільшуючи свій розмір, деформовані об'єкти набувають овальної та півмісячної форм, не створюючи окремих фрагментів. Розміри деформованих об’єктів були від $1,3 \times 2,5$ до $1,5 \times 2,7$ см.

Другою спільною ознакою $є$ те, що ушкодження м'яких і кісткової тканин були досить значними за обсягом. Проте кожна куля залишала свої індивідуальні морфологічні ознаки Найбільші ушкодження спричиняли експансивні кулі, що споряджені в патрони "RWS", при цьому спостерігалися великі за обсягом ушкодження як на вході, так і виході. При пострілі в стегно з дистанції 3 м відмічалася розривна дія кулі зі значними дефектами м'яких тканин розмірами 10 х $12 \pm 1$ см з розривами по краях і багатоуламковими дрібнофрагментованими переломами стегнової кістки, що не співставляються між собою за рахунок значної кількості дрібних кісткових фрагментів. У внутрішніх органах (печінка та легені) куля "RWS" спричиняла значні вогнища руйнування паренхіми, утворюючи розриви та розміжження тканини, при потраплянні в порожнину серця відбувалася гідродинамічна дія з повним руйнуванням органу. Внаслідок дії патронів "Gесо" ушкодження біологічних об'єктів були значними, проте меншими порівняно з кулями “RWS”. На м'яких тканинах спостерігався дефект як на вхідному, так і вихідному вогнепальних отворах. При пострілі з дистанції 3 м вхідна рана на стегні була неправильно округлої форми діаметром 4,2-4,4 см з розривами шкіри по краях і багатоуламковими переломами стегнової кістки, уламки якої не співставлялися. На внутрішніх органах утворювалися наскрізні ушкодження 3 дефектом тканини, розміжженням і розривами паренхіми органу. Ушкодження, що утворилися від дії куль, які споряджені в патрон "Sellier \& Bellot", були найменшими за обсягом, проте вхідна та вихідна вогнепальні рани були 3 дефектами тканини, при пострілі 3 дистанції 3 м рана мала овальну форму діаметром 4,5-5 см 3 центральним дефектом тканини, проте без додаткових розривів по краях. На стегновій кістці утворювався багатоуламковий перелом, уламки були досить крупними, проте погано співставлялися між собою за рахунок викришування кісткової тканини по краях перелому. На внутрішніх органах відмічалися наскрізні ушкодження з нерівними краями, центральним дефектом тканини та незначними розривами по краях.

Третьою спільною ознакою $є$ те, що при пошкодженні білої бавовняної тканини при пострілах з дистанцій 1, 2, 3 та 5 м та камуфльованої тканини 3 дистанцій 50 і 100 м утворювалися пошкодження круглої, неправильно округлої чи неправильно квадратної форм з центральним дефектом тканини. Проте при детальному дослідженні було виявлено ряд індивідуальних ознак. Пошкодження, що утворилися при пострілах патронами “RWS”, на білій бавовняній тканині були круглої форми з повним центральним дефектом тканини, нитки по краях розділені на одному рівні, волокна гладкі, нерозволокнені. У просвіт пошкодження з чотирьох боків у вигляді квадрата виступають нитки полотна, довжина яких збільшується зі збільшенням дистанції пострілу. На камуфльованій тканині пошкодження наближені до квадратної форми, проте теж мають рівні та чіткі краї. Ця індивідуальна особливість утворюється завдяки жолобоподібному заглибленню в нижній частині кулі, яке має виражені краї, внаслідок чого відбувається розділення тканини на одному рівні. Пошкодження, що утворилися від дії куль, що споряджені в патрони “Geco", були подібними до пошкоджень від дії куль "RWS” за формою та розмірами, проте мали нерівні краї, тобто розділені на різних рівнях нитки полотна, що виступали в просвіт дефекту та були значно розволокнені. У пошкодженнях від кулі, що споряджена в патрон “Sellier \& Bellot", вхідні отвори на бавовняній та камуфльованій тканинах мали нечітку округлу форму, центральний дефект тканини та нерівні краї, тобто нитки полотна були розділені на абсолютно різних рівнях, їхні волокна значно розволокнені.

Четвертою спільною ознакою $є$ те, що фактори, які супроводжували постріл, зокрема частково обгорілі порошинки, відкладалися на відстань до 2,5 м при експериментальних пострілах усіма трьома видами патронів. Проте при розкритті кожного з патронів встановлено, що порошинки мають різні форму та розміри. Порох у гільзі патрона “Gесо" має темно-сірий колір з блиском, округлу форму зерен діаметром 0,1 см, товщиною 0,1-0,13 см. Порох у гільзі патрона "RWS" має темно-сірий колір з блиском, циліндричну форму зерен довжиною 0,18-0,2 см, діаметром 0,1см. Вони найкрупніші з-поміж трьох досліджуваних патронів. Порох у гільзі патрона "Sellier \& Bellot” має темно-сірий колір з блиском, циліндричну форму зерен діаметром 0,1 см, товщиною 0,1-0,15 см. 
П’ятою спільною ознакою є наявність металізації, тобто при застосуванні контактно-дифузійного методу кольорових відбитків було встановлено, що такі метали, як мідь і свинець, відкладаються в усіх випадках, 3 неоднаковою інтенсивністю, проте їх можна виявити при пошкодженні будь-якими з вище досліджених патронів. Однак при проведенні РФСА в кожному досліджуваному об'єкті виявлявся індивідуальний склад металів. Оболонка кулі "RWS" на 94,22 $\pm 0,1 \%$ складалася 3 міді, 5,6 $\pm 0,1 \%$ - цинку та $0,11 \pm 0,01 \%$ заліза. Таким чином в неї найміцніша оболонка, вона значно збільшується в об’ємі не фрагментуючись, утворюючи найзначніші ушкод-

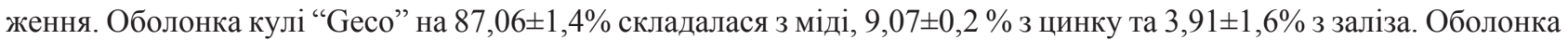

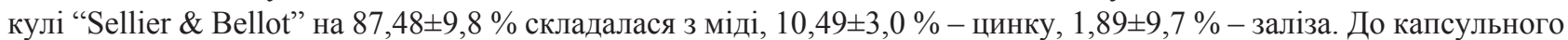
складу входили такі компоненти, як мідь, цинк, залізо, барій, свинець, фосфор і кальцій. При проведенні РФСА поясків обтирання з вогнепальних пошкоджень на бавовняній та камуфльованій тканині були виявлені хімічні елементи, що містилися в кулі, капсульному складі патрона чи з поверхні каналу ствола, а також їх розподіл стосовно відстані пострілу та патрону, яким здійснювався постріл.

\section{ВИСНОВКИ.}

Таким чином, провівши ряд експериментальних вогнепальних ушкоджень патронами 8х57мм, що споряджені експансивними кулями було встановлено, що на формування ушкоджень внутрішніх органів суттєво впливали конструктивні особливості експансивної кулі. Куля “RWS”, що розкривалася, спричиняла значні ділянки руйнування паренхіми органів, утворюючи розриви та розміжження тканини. При потраплянні в порожнину серця спостерігалася гідродинамічна дія з повним руйнуванням органу. Куля “Gесо” спричиняла менш руйнівні, проте досить значні ушкодження з розміжженням і розривами по краях за рахунок фрагментування. Ушкодження від дії куль “Sellier \& Bellot”, що деформувалися, були найменшими з дефектами тканини, проте без розривів паренхіми. На конструктивні особливості кулі значним чином впливали склад металів оболонки кулі. Найміцнішою виявилася оболонка кулі “RWS”, що й утворювала найбільші за об'ємом ушкодження. При дослідженні пошкоджень на тканині було встановлено, що куля “RWS" має індивідуальні особливості, що не зустрічалися в жодної іншої кулі. Це здатність спричиняти пошкодження з дефектом тканини, залишаючи краї рівними, тобто нитки були чітко розділені на одному рівні за рахунок жолобоподібного заглиблення в задній частині кулі. Пошкодження від кулі “Geco” були чіткими, проте краї в дефекті тканини були нерівними, волокна розволокнені. Куля "Sellier \& Bellot” спричиняла пошкодження нечіткої форми з нерівними розволокненими краями. Отже, велике значення під час проведення таких експертиз в першу чергу має дослідження пошкоджень на одязі та визначення хімічного складу в поясу обтирання навколо пошкодження.

\section{Література}

1. Frankonia Seit 1908. Dem Besonderer geburt immer auch eine besondere Präsentation 100 Share Passion. — 2008. $-575 \mathrm{p}$.

2. Назаров Ю. В. Применение эмиссионного спектрального анализа при судебно-медицинской экспертизе огнестрельных повреждений причиняемых эластичными поражающими элементами / Ю. В. Назаров, Т. В. Лебедева // Теория и практика судебной медицины. - СПб., 2006. - С. 90-93.

3. Филипчук О. В. Судово-медична криміналістика: підручник / О. В. Филипчук, О. М. Гуров. — Х.: Діса плюс, 2013. - 640 с. — (Медицина ХХІ століття).

4. СП “Шмайсер”: смелый взгляд в будущее // Оружие и охота. - 2003. — № 6. — С. 2-3.

\section{СРАВНИТЕЛЬНАЯ СУДЕБНО-МЕДИЦИНСКАЯ ХАРАКТЕРИСТИКА ПОВРЕЖДЕНИЙ ЭКСПАНСИВНЫМИ ПУЛЯМИ, КОТОРЫЕ СНАРЯЖЕНЫ В ОХОТНИЧЬИ ПАТРОНЫ 8Х57 ММ, ТАКИХ ТОРГОВЫХ МАРОК, KAK «GECO», «RWS» И «SELLIER \& BELLOT»}

\section{Н. В. Бартошик}

Резюме: В статье изложенные результаты экспериментальных исследований огнестрельных повреждений, вызванных охотничьими патроны 8х57мм, снаряженных экспансивными пулями, разных торговых марок, которые проводились по объектам биологического и небиологического происхождения из разных расстояний, и представлена судебно-медицинская характеристика общих и отличных морфологических знак.

Ключевые слова: Огнестрельные повреждения, экспансивные пули, расстояние выстрела, дефект ткани. 


\title{
COMPARATIVE FORENSIC ANALYSIS OF GUNSHOT INJURIES CAUSED BY 8X57MM CARTRIDGES EQUIPPED WITH GECO, RWS AND SELLIER\&BELLOT EXPANDING BULLETS
}

\author{
N. V. Bartoshyk
}

Abstract: The paper discusses the results of the experimental study of the gunshot injuries caused by $8 \times 57 \mathrm{~mm}$ cartridges equipped with expanding bullets from different manufacturers to biological and non-biological objects at various distances. Forensic description of the common and distinctive morphological features is presented.

Key words: gunshot injuries, expanding bullets, shooting distance, fabric damage.

УДК 340.6: 614.23/.25: 616-036.8

\section{ЕКСПЕРТНА ОЦНКА НАДАННЯ МЕДИЧНОЇ ДОПОМОГИ ПРИ ТРАВМАХ, ЗАХВОРЮВАННЯХ ТА ОТРУСННЯХ У РІЗНИХ ВІДДІЛЕННЯХ БАГАТОПРОФІЛЬНОЇ ЛІКАРНІ ШВИДКОЇ МЕДИЧНОЇ ДОПОМОГИ}

\author{
СПлетенецька А. О., Гуріна О. О., Попов В. А., Рощін Г. Г. \\ НМАПО імені П. Л. Шупика
}

\begin{abstract}
Резюме. Одними з найскладніших судово-медичних експертиз $є$ експертизи, що стосуються визначення правильності надання медичної допомоги. Метою дослідження було проведення аналізу медичної документації хворих у випадках розбіжностей клінічного та судово-медичного діагнозів по основному та ускладненням для виявлення основних причин невірно встановленого діагнозу за даними багатопрофільної лікарні швидкої та невідкладної медичної допомоги за 2006-2012 рр. Після статистичної обробки даних була проведена експертна оцінка летальності багатопрофільної лікарні, що включала у себе більш детальне вивчення надання медичної допомоги пацієнтам. Зокрема, виділялися причини невірно встановленого клініцистами діагнозу, а також порівнювалися випадки неспівпадінь основного клінічного діагнозу з судово-медичним у випадках наявності травми, захворювання або отруєння. Після цього оцінювалася медична допомога, зокрема і медикаментозне лікування, яке було призначено лікарями. Ці дані співставлялися з тим, яка медична допомога була реально потрібна хворим з урахуванням безпосередньою причиною смерті.
\end{abstract}

Ключові слова: судово-медична експертиза, надання медичної допомоги, травма, захворювання, отруєння.

ВСТУП. Провідну роль в розслідуванні злочинів, що були вчинені під час надання медичної допомоги лежить на судово-медичній експертизі. Проведення експертиз з приводу дефектів надання медичної допомоги регулюється Законом України «Про судову експертизу» від 25 лютого 1994 р. № 4038-ХІІ та Інструкції «Про проведення судово-медичної експертизи», затвердженої наказом Міністерства охорони здоров'я України від 17 січня 1995 р. № $6[2,3]$. Одними з найскладніших судово-медичних експертиз є експертизи, що стосуються визначення правильності надання медичної допомоги. Основними причинами цього є недостатня кількість нормативних актів, що регулювали б надання медичної допомоги населенню, та недосконалістю правової бази $[1,7,8]$. Для об'єктивної та вірної оцінки надання медичної допомоги судово-медичним експертам, на яких покладено таке завдання, слід ретельно вивчати всі тонкощі цієї допомоги на кожному етапі з урахуванням вимог чинного законодавства України $[4,5,6]$. Для вирішення питань щодо надання медичної допомоги потрібно проаналізувати у динаміці на кожному етапі обсяг, тактику, повноту, своєчасність призначених хворому лікувально-діагностичних заходів.

Метою дослідження було проведення аналізу медичної документації хворих у випадках розбіжностей клінічного та судово-медичного діагнозів по основному та ускладненням для виявлення основних причин невірно встановленого діагнозу за даними багатопрофільної лікарні швидкої та невідкладної медичної допомоги (ЛШНМД) за 2006-2012 pp.

Матеріали і методи. Матеріалом досліджень були 207 медичних карток стаціонарних хворих, що знаходились на лікуванні враховувалися наступні показники: відділення (токсикологічне, нейрохірургічне, відділення полі травми, відділення інтенсивної терапії та екстреної допомоги (ВIT та ЕД), травматологічне, невідкладної терапії), стать та вік хворого, дата госпіталізації, дата смерті, тривалість лікування, час госпіталізації, час настання смерті, ким був направлений хворий (ШМД, поліклініка, самозвернення), діагноз з супровідного листа ШМД, якими спеціалістами був оглянутий хворий, які аналізи додаткові методи обстеження проводилися, клінічний діагноз (основний, ускладнення, супутній, судово-медичний діагноз, розходження діагнозів по основному та по ускладненням (повне та неповне), причина цього розходження. Обробка та аналіз даних проводилися в програмних пакетах OpenOffice (Base, Calc, Writer, Draw, Math), GNU Octave зі збереженням вихідних документів у форматі *.doc, *.xls. 